University for Business and Technology in Kosovo

UBT Knowledge Center

UBT International Conference

2013 UBT International Conference

Nov 1st, 3:00 PM - 3:10 PM

\title{
Measuring The Impact Of Transport In The Developing Economies
}

Ylber Limani

University for Business and Technology, ylber.limani@ubt-uni.net

Ermal Lubishtani

University for Business and Technology, elubishtani@ubt-uni.net

Follow this and additional works at: https://knowledgecenter.ubt-uni.net/conference

Part of the Business Commons

\section{Recommended Citation}

Limani, Ylber and Lubishtani, Ermal, "Measuring The Impact Of Transport In The Developing Economies" (2013). UBT International Conference. 30.

https://knowledgecenter.ubt-uni.net/conference/2013/all-events/30

This Event is brought to you for free and open access by the Publication and Journals at UBT Knowledge Center. It has been accepted for inclusion in UBT International Conference by an authorized administrator of UBT Knowledge Center. For more information, please contact knowledge.center@ubt-uni.net. 


\title{
Measuring The Impact Of Transport In The Developing Economies
}

\author{
Ylber Limani, Ermal Lubishtani \\ University for Business and Technology \\ Department of Business, Management and Economy \\ e-mail: ylber.limani@ubt-uni.net \\ University for Business and Technology \\ Department of Business, Management and Economy \\ e-mail: elubishtani@ubt-uni.net
}

\begin{abstract}
This paper discusses the correlation between transport and the economy. The rationality of doing this research lies on the need for a clearer definition of transport to economic development and for the economic growth of a country or a region. The developing economies should plan their transport based on their economic projections and they should avoid the policies based on infrastructure development and transport resources. In order to discuss this assumption in this paper have correlation analys is is used to observe the transport growth and GDP growth in developed and in developing countries using the data from official bureaus and from the recent literature. Furthermo re, the identification of the economic benefits of transport and opposite consequences of transport is performed in order to analyze and compare the gross value of transport in developing and developed economies. To achieve this the correlation analysis is performed. As a result we have projected the differences of increase of GDP and transport in different economies in mid and in long term considering two scenarios.
\end{abstract}

Key words: Economy, GDP, development, transport, impact, sustainability, developing countries.

\section{Introduction}

Historically, transport planning was oriented on mobility-based approaches, which have encouraged more travel distance and more speed. To achieve such goals planners and decision makers where conditionally obligated to encourage the production growth of transport resources and development of related infrastructure (Banister and Berechman, 2000). The ultimate goal of achieving more mobility and more speed was justified with the concepts of reaching more space and saving more time (Litman, 2013). These concepts have converged with the desirable economic benefits of infrastructure projects and transport resources production. Orthodox planning evaluates trans port system performance based primarily on mobility, which results in more traffic for motorized vehicles, and less possibilities to walk or to use public transport, perceiving that the latest represent the sustainable transport elements.

However, transport growth has been stimulated by the economic development and economic growth and it was not originally generated by infrastructure development and by production of resources (Banister and Berechman, 2000). Transport is an important sector of the overall ec onomy, nevertheless it is the product of the economy itself. Considering our two contradicting assumptions, we have developed a new hypothesis about the context of this study. We consider that transport, and thereby transport infrastructure and transport resources should be planned and developed based on economic projections, and the policy of building more infrastructure and producing more transport resources should be well-adjusted with the projections of economic development and economic growth of a region or a country. The research method is sustantial empirical as it tries to test the relationship between transport infrastructure and resources, and economic development and growth variables.

The case study of the European Union (EU) and United States of America (USA) Goods transport performance evaluation is used to assess the relationship of transport and the economy. The findings are further evaluated and compared with the results fromthe study of main developing world economies. The conclusion is that developing economies have achieved more economic growth with less developed infrastructure and lower production and use of transport resources compared with developed economies. This conclusion is aimed to support our main hypothes is. This res earch is limited to four selected Goods 
transport modes: Road, Rail, Inland Waterways and Pipelines. The performance of selected transport modes is measured against the amount of tones kilometers travelled (tkm).

\section{Measuring The Goods Transport Performance Of Developed And Developing Economies: The Case Study Of Eu And Usa}

The evidence is that Goods transport is generated by economic activity having a tendency to respond to the fluctuations within this activity. The changing transport demand level is affected by the trade level between regions and countries. There is an indication transport performance increased continuously by overstressing system capacity in many countries before 2008 (EC Energy and Transport, 2011). The certain indications provided by practically all major transport indicator sources around the world notify about transport trends alerting for continuously increase demand for transport, particularly for Goods transport (EEA, 2010). The demand for transport is generated by the economic development and economic growth of countries and regions, and thereby transport should be considered one of the major components of the economy. We believe that this research based on assumptions made in this Section should be a valuable knowledge for planners and decision makers in the developing countries. The research on Goods transport performance in the EU27 and in the USA for a selected time period show some interesting and valuable results, which are shown in the Figure1, respectively in the Figure 2. Total Goods transport performance by four modes as displayed in the Figure 1 in the EU27 grows from 1995 to 2009 for about $35 \%$. Road and sea transport modes show most increased performance. The shadowed areas in the Figure 1 and in the Figure 2 displays the time limitation of this research, i.e., In the following sections the research is focused on analyzing the performance of transport and the economic impact of transport in main leading world economies, including here some of developing regions. Analysing the Figure 1 can be concluded that Goods transport performance by road in the EU27 has increased continuously. The Figure 2 shows that in the USA the transport performance measured by transport modes differs from that in the EU27. A significant difference exists particularly in rail Goods transport. Goods transport in the USA has increased from 1990 to 2007, while in the EU27 Goods transport by Rail has marginal increased performance between 2006 and 2008. Further in this research we have examined the selected transport modes for the period from 2001 to 2006. This period is selected where transport was not affected by credit crisis period that arose in 2007 in the USA and in 2008 in the EU. The average performance by mode, Goods transport in the EU27 and in the USA is presented in the Table 1 and the correlation between two regions is shown. Comparing the data from the Table 1 and from the figures 1 and 2 we have concluded that in the EU27 in average 71, 6\% of Goods transport is performed by road, and $17.1 \%$ of Goods transport are performed by rail. In the USA we see a different picture where 32,8 of Goods transport is carried out by road, and $43.3 \%$ by rail.

Fig. 1: Performance by mode of Goods transport system 1995-2009 in EU27(Source: Eurostat 2009,

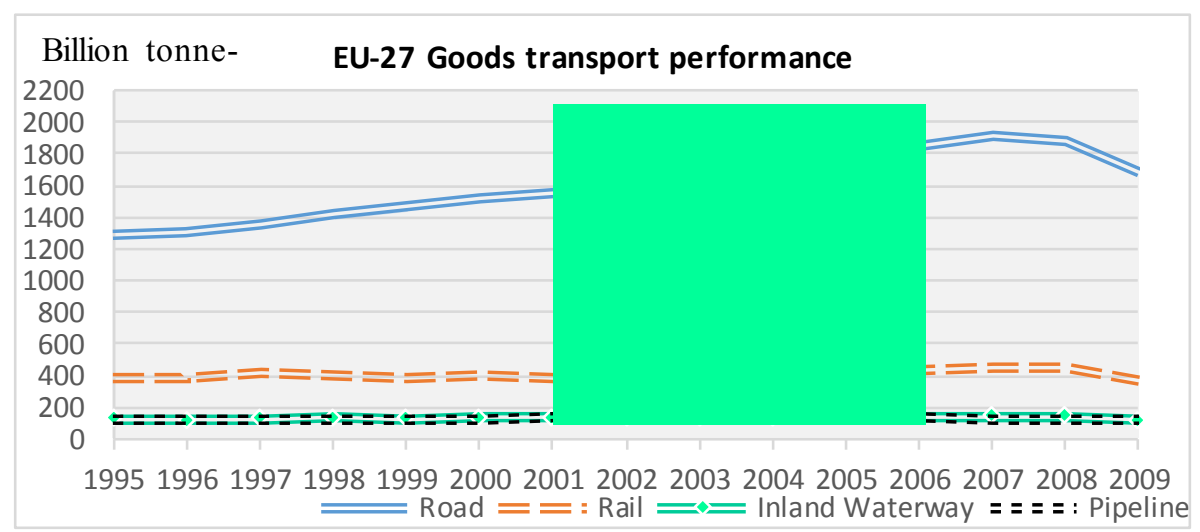

EC Energy and Transport 2011) 


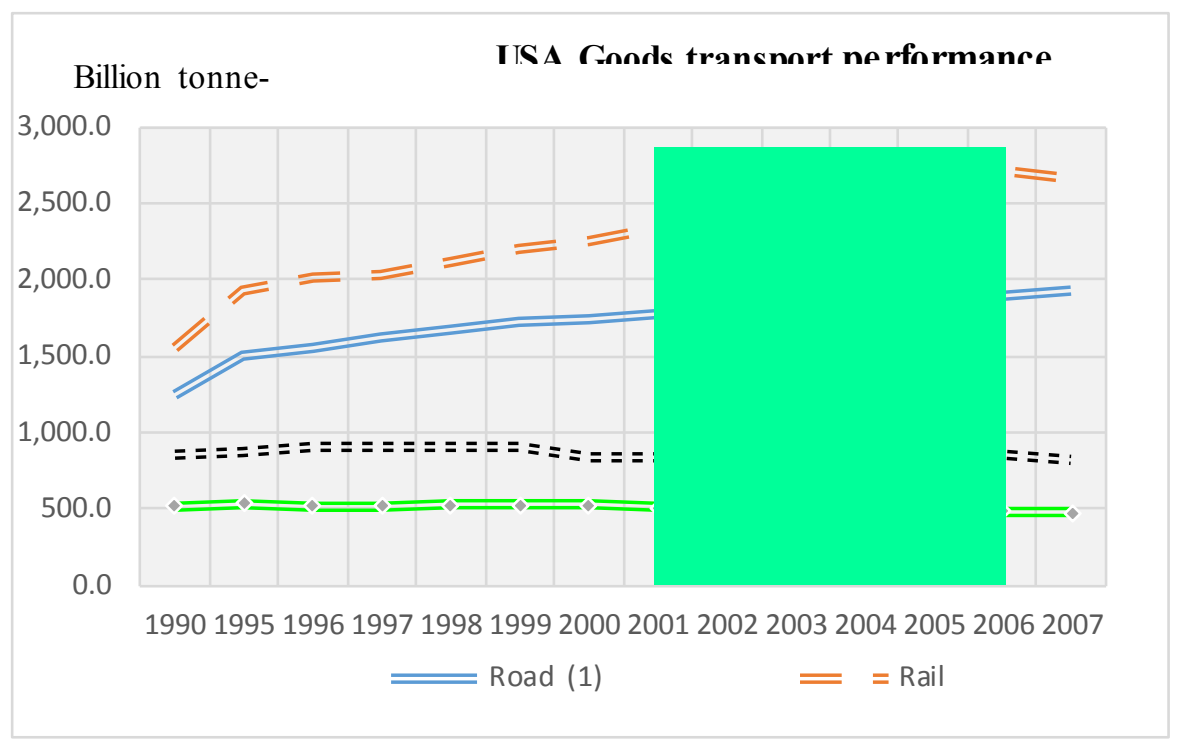

Fig. 2: Performance by mode of Goods transport system 1990-2007 USA (Source: EC Energyand Transport 2010)

Viewed in the terms of sustainable development we conclude that the USA transport planning and execution is more sustainable comparing with Goods transport planning and execution of the EU27. This assumption may be argued using the evidences showing that Road transport mode is less sustainable than Rail transport mode, since it uses more energy, courses more accidents, and pollutes the air, land and soil.

Another remarkable evidence is that Road transport in the EU27 increases faster compared with the same mode in the USA for the whole presented time period. Inland waterways and pipeline transport modes show no significant change, respectively it may be concluded that in this case is no increase in performance in both study areas.

Table 1: Average performance by mode, Goods transport EU27 2001-2006 and USA 20012006

\begin{tabular}{|c|c|c|c|c|c|}
\hline EU27 & Road & Rail & Inland Water- ways & Pipe- lines & Total \\
\hline $2001 / 2006$ & & & & & \\
\hline Billion tkm & $\begin{array}{l}1695 . \\
21\end{array}$ & $\begin{array}{l}405.4 \\
1\end{array}$ & 133.73 & 132.48 & 2366.83 \\
\hline$\%$ & 71.6 & 17.1 & 5.7 & 5.6 & 100 \\
\hline \multicolumn{6}{|l|}{ USA } \\
\hline Billion tkm & 1858 & $\begin{array}{l}2453 . \\
26\end{array}$ & 490.96 & 861.6 & 5663.82 \\
\hline$\%$ & 32.8 & 43.3 & 8.6 & 15.3 & 100 \\
\hline
\end{tabular}

Table 2: Average annual change Goods transport in the EU27 (\% per year)

\begin{tabular}{llllll}
\hline EU27 & Road & Rail & $\begin{array}{l}\text { Inland } \\
\text { Waterways }\end{array}$ & Pipelines & Total-Excluding Sea and Air \\
\hline $1995-2008$ & 2.9 & 1.1 & 1.3 & 0.6 & 1.45 \\
$2000-2008$ & 2.7 & 1.2 & 1.0 & -0.3 & 1.15 \\
$2007-2008$ & -1.9 & -2.3 & -1.2 & -2.2 & -1.9 \\
\hline
\end{tabular}

Source: EC Energy and Transport 2010 
Table 3: Average annual change Goods transport systemin the USA (\% per year)

\begin{tabular}{llllll}
\hline USA & Road (1) & Rail & $\begin{array}{l}\text { Inland } \\
\text { Waterways }\end{array}$ & Pipelines & Total \\
\hline $1990-1995$ & 4.0 & 4.4 & 0.7 & 0.6 & 3.1 \\
$1995-2000$ & 2.9 & 3.3 & -0.3 & -0.8 & 2.1 \\
$2000-2007$ & 1.4 & 2.4 & -1.5 & -0.5 & 1.3 \\
\hline
\end{tabular}

Source: EC Energy and Transport 2010

There is no mode of transport showing an increase in performance from 2000 to 2008 . The conclusion from the data presented in Tables 3 and 4 is that transport is dependent on economic development and growth. The performance of Goods transport of main world economies including some of developing countries

Goods transport productivity in the EU27 in the USA and in some large developing economies has been continuously improved by inconstant optimization of transport means and infrastructure. It is evident that Multimodal transport is positioned high in policy agendas of many countries and regions, since it plays a vital role linking-up markets physically and removing obstacles to the delivery of transport services. For the purpose of study simplification the year 2006 is taken as a situation where transport performance of various developed and developing economies is measured against tones -kilometers indicator.

Table 4: Comparis on of performance of Goods transport of main world economies in 2006 (in billion tonnes-kilometer and \%)

\begin{tabular}{|c|c|c|c|c|c|c|c|c|c|c|}
\hline Btkm & EU27 & & USA & & Japan & & China & & Russi & \\
\hline Road & 1854 & $72.2 \%$ & 1885.2 & $32 \%$ & 347 & $\begin{array}{l}94 \\
\%\end{array}$ & 975 & $\begin{array}{l}21.07 \\
\%\end{array}$ & 201 & $4 \%$ \\
\hline Rail & 440 & $\begin{array}{l}17.14 \\
\%\end{array}$ & 2709.6 & $46 \%$ & 23 & $6 \%$ & 2195 & $\begin{array}{l}47.44 \\
\%\end{array}$ & 1951 & $41 \%$ \\
\hline $\begin{array}{l}\text { Oil } \\
\text { pipeline }\end{array}$ & 135 & $5.26 \%$ & 848.7 & $14 \%$ & . & . & 166 & $3.59 \%$ & 2499 & $53 \%$ \\
\hline $\begin{array}{l}\text { Inland } \\
\text { waterway }\end{array}$ & 138 & $5.38 \%$ & 486 & $8 \%$ & . & . & 1291 & $\begin{array}{l}27.90 \\
\%\end{array}$ & 58 & $1 \%$ \\
\hline $\begin{array}{ll}\text { Total } & 4 \\
\text { modes } & \end{array}$ & 2567 & $\begin{array}{l}100.0 \\
\%\end{array}$ & 5929.5 & $\begin{array}{l}100 \\
\%\end{array}$ & 370 & $\begin{array}{l}100 \\
\%\end{array}$ & 4627 & $100 \%$ & 4709 & $\begin{array}{l}100 \\
\%\end{array}$ \\
\hline
\end{tabular}

Source: EC Energy and Transport 2010, Eurostat 2009, U.S. DOT 2010

Russia`s total Goods transport performance is higher compared with the EU-27 where the oil pipeline $(53 \%)$ and rail $(41 \%)$ has greatly influenced the total goods transport performance. Table 2.8 reflects the economic growth trends respectively the forthcoming recession in the USA and EU27, while in the countries like China and Russia shows the increase in goods transport performance.

EU27 goods transport performance in 2009 has reached the altitude of 2413.51 billion tkm in a total of four modes, while in 2006 it was 2567 billion tkm. This means there is a decrease in transport performance for about

The difference showed an increase of total goods transport performance by about $1 \%$ in 2008 compared with Goods transport performance in 2006 in the EU27. In the USA the same calculation for the years 2006 and 2008 shows that the performance of total goods transport has declined in 2008 by about 66.5 billion tkm or by about $1.1 \%$.

The Table 7 displays the remarkable results from the correlation analysis of Goods transport performance in main developed and developing economies. There is strong evidence of decrease of Goods transport performance in all developed economies from 2006 to 2008 and 2010. Such a decline if Goods transport performance has occurred certainly due to economic recession.

This finding validates our assumptions made in the Section 2 of this research work. Thereby the conclusion is that transport is a part of the economy itself, and it should it be planned corresponding to 
the economic projections of a country or a region. The performance of passenger transport is similar to the Goods transport performance of studying economies.

Table 5: Comparis on of performance of Goods transport of main world economies in 2008, 2009, and 20010 (in billion tonnes-kilometer and \%)

\begin{tabular}{|c|c|c|c|c|c|c|c|c|c|c|}
\hline \multirow[t]{2}{*}{ Billion tkm } & \multicolumn{2}{|l|}{$\overline{E U 27}$} & \multicolumn{2}{|l|}{ USA } & \multicolumn{2}{|l|}{ Japan } & \multicolumn{2}{|l|}{ China } & \multicolumn{2}{|c|}{ Russia } \\
\hline & 2009 & & 2008 & & 2010 & & 2009 & & 2010 & \\
\hline Road & 1755.61 & $73 \%$ & 922.9 & $19 \%$ & 334.7 & $94 \%$ & 3718.9 & $58 \%$ & 199 & $4 \%$ \\
\hline Rail & 389.9 & $16 \%$ & 2525.4 & $52 \%$ & 20.4 & $6 \%$ & 2523.9 & $39 \%$ & 2011 & $43 \%$ \\
\hline Oil pipeline & 120.6 & $5 \%$ & 919.6 & $19 \%$ & & & 202.2 & $3 \%$ & 2382 & $51 \%$ \\
\hline $\begin{array}{l}\text { Inland } \\
\text { waterway }\end{array}$ & 147.4 & $6 \%$ & 456.4 & $9 \%$ & & & $\begin{array}{l}1 \\
803.3\end{array}$ & & 54 & $1 \%$ \\
\hline $\begin{array}{l}\text { Total, } \\
\text { modes }\end{array}$ & 2413.51 & & 4824.3 & & 355.1 & & 6445 & & 4646 & \\
\hline
\end{tabular}

Source: EC Energy and Transport 2012

Table 6: The difference in Goods transport performance of main world economies compared years 2006 and 2018, 2009, respectively 2010

\begin{tabular}{llllll}
\hline Billion tkm & EU27 & USA & Japan & China & Russia \\
\hline Total 4 modes in 2006 & 2567 & 5929.5 & 370 & 4627 & 4709 \\
Total 4 modes in 2009/2010 & 2413.5 & 4824.3 & 355.1 & 6445 & 4646 \\
Difference from 2006 to 2010 & -153.5 & -1105.2 & -14.9 & $\mathbf{1 8 1 8}$ & -63 \\
\hline
\end{tabular}

Source: EC Energy and Transport 2010

\section{The Economic Impact Of Transport}

Transport magnitude is influenced from economic growth and development, while the physical characteristics of transport system influence the location and dynamics of economic activities. To support this assumption the arguments have been built for performing analys is of the economic growth developed and developing economies. To determine the impact of transport on the economy the Gross Domestic Product (GDP) indicator has been evaluated. Consecutively, the transport contribution to real GDP of main economies and employment in the transport sector has been indicated. Because of lack of data relating to employment shares of transport in the case of China and Russia the study with reference to these countries has been limited to real GDP.

The transport industry in the Europe contributes for around 7\% of GDP and for around 5\% of employment in the EU (EC, 2006). In 2006 total annual employment in the USA was about 143.4 million people, whereas transport sector contributed for 9.12 million (U.S. DOT 2010). In Japan in 2006 were 63.82 million people employed, and in transport sector were 3.06 million people employed contributing by about $5 \%$ of the total employment in Japan (Ministry of Internal Affairs and Communication 2011).

Table 7: Transport impact on GDP growth of developed and developing economies

\begin{tabular}{lllllll}
\hline $\begin{array}{l}\text { Expressed } \\
\text { in (\%) in }\end{array}$ & $\begin{array}{l}\text { Real } \\
\text { growth }\end{array}$ & GDP & $\Delta \mathbf{1 0} / 06$ & $\begin{array}{l}\text { Projected } \\
\text { GDP growth }\end{array}$ & $\begin{array}{l}\text { Transport } \\
\text { contribution to } \\
\text { Real GDP in \% }\end{array}$ & $\begin{array}{l}\text { Employment } \\
\text { In } \%\end{array}$ \\
& & & & & \\
\hline
\end{tabular}




\begin{tabular}{llllllll}
\hline & $\mathbf{2 0 0 6}$ & $\mathbf{2 0 1 0}$ & & $\mathbf{2 0 1 1}$ & $\mathbf{2 0 1 2}$ & $\mathbf{2 0 0 6}$ & $\mathbf{2 0 0 6}$ \\
EU-27 & 3.2 & 1.8 & -1.6 & 1.7 & 1.4 & 7 & 4.5 \\
USA & 2.7 & 3.0 & -0.3 & 1.5 & 1.8 & 9.8 & 6.6 \\
Japan & 2.0 & 4.0 & -2.0 & 0.5 & 2.3 & $\mathrm{U}$ & 5 \\
China & 12.6 & 10.3 & -2.3 & 9.5 & 9.0 & $\mathrm{U}$ & $\mathrm{U}$ \\
Russia & 8.2 & 6.9 & -1.3 & 8.9 & 6.3 & $\mathrm{U}$ & $\mathrm{U}$ \\
\hline
\end{tabular}

Source: IMF 2011, EC Energy and Transport 2011, U.S.DOT 2011, EC 2006

Data displayed in the table 8 provides with basic perception about the spreading of transport contributions to the economy in terms of GDP, and employment proportion. Total transport GDP related in finaldemand (this concept includes the expenditures by end users ofgoods and services for transport purposes). It includes the transport component of the four components of GDP: personal consumption expenditures, government expenditures and investment, business investment, and net exports.

In essence, transport final demand measures the size of transport function in relation to GDP. Transport capital projects can be justified only if they generate sufficient transport benefits. Otherwise attempts for rationalization of their implementation based on supposed and unproven economic development benefits are fundamentally mistaken and may create environments for the implementation of poorer transport projects (Banister and Berechman, 2000). For transport investments two main decision criteria should be clearly defined:

Primary decision criteria for transport investments should be based on the social rate of return fromtheir primary transport benefits; Economic development effects are secondary decision criteria that cannot replace transport output evaluation (primary transport benefits). From this supposition it can be argued that additional transport capacity, i.e. Infrastructure and resources is not reasonable when current capacity is not used. This undertaking would intensively represent poor economics. It is assumed that transport investments are carried out incrementally through the implementation of individual projects. Therefore the relationship between the project's primary accessibility benefits and economic development should be discovered at project level. This situation would require a microeconomic analysis. It is not in the scope of this research to examine the complexity of causal reality related to transport economics, however the presented statistics correspondingly support the assumption related to the relationship between transport and the economy at the level initiated by this research.

\section{Conclusions And Recommendations}

The first valuable conclusion of this research is that transport system has changed continually by its performance. The change was not always positive considering the increase of Road transport mode performance measured in tone-kilometers. The Road transport is considered to have significant negative impact on the environment and on the society. Despite of such argument, this mode of transport has continually increased over time and space and is considered to be a major economic contributor providing mobility.

The correlation analysis of performance of Goods transport between EU27 and the USA show the main differences in Rail and Road share. Taking into account the sustainability criteria, USA have more sustainable transport indications compared with EU27, since it favors the transport of Goods by Rail.

More intensive research, sufficient and flexible policy practices, and smarter investment practices are required to achieve enhanced balance between current transport modes.

Transport project investments are dependent on certain necessary market conditions. In the case of countries like WBCs and Kosovo it would be important to identify and to validate the presence of such market conditions. In the absence of market conditions transport investments possibly will generate improved accessibility and provisional mobility. However, if market conditions exist and policy measures are suitable and robust, transport project investments can possibly promote local and regional 
development and potentially will contribute to the improvement of the environment. A set of suggestions that may lead to adequate transport project investments is presented as follows:

1. The projects should be associated with policy, and plans and programs.

2. The transport projects should be carried out as a part of the overall network, not as single projects.

3. The decision making processes need to be aligned at all planning levels.

4. Transport planning should be deliberated as a division ofland use, community development and urban development, and it should not be focused only on infrastructure constructions.

5. Demand management should play a significant role on determining how transport investments should be distributed.

6. The transport investment projects should not miscalculate environmental and social impacts of transport projects, and they should be focused on the impacts which produce effects across the whole network, not only on projects locations.

\section{References}

1 Banister D. Berechman Y. (2000). The Economic Development Effects of Transport Investments. UCL Press, London.

2 EC (2006). Commission Staff Working Document: Impact Assessment of the Communication "Keep Europe Moving”. Sustainable mobility for our continent. Brussels.

3 EC Energy and Transport (2010). EU Energy and Transport in Figures. Statistical pocketbook 2009. Office for Official Publications of the European Communities, Luxemburg.

4 EC Energy and Transport (2011). EU Energy and Transport in Figures. Statistical Pocketbook 2011. Office for Official Publications of the European Communities, Luxemburg.

5 EC Energy and Transport (2012). EU Energy and Transport in Figures. Statistical Pocketbook 2011. Office for Official Publications of the European Communities, Luxemburg.

6 EEA (2010). Towards a resource-efficient transport system. TERM 2009: indicators tracking transport and environment in the European Union. European Environmental Agency, Copenhagen.

7 Eurostat (2009). Panorama of Transport. Office for Official Publications of the European Communities, Luxemburg.

8 International Monetary Fund (2011). World Economic Outlook. World Economic and Financial Surveys. International Monetary Fund, Publication Services, Washington D.C.

9 Litman T. (2013). Towards More Comprehensive and Multi-modal Transport Evaluation. Victoria Transport Policy institute [online]. Available at: http://www.vtpi.org/comp_evaluation.pdf

10 Ministry of Internal Affairs and Communication (2011). Statistics Bureau, Director-General for Policy Planning \& Statistical Research and Training Institute, Japan. [Online]. Available at: http://www.stat.go.jp/english/data/roudou/lngindex.htm

11 U.S. DOT (2010). National Transportation Statistics 2010. Research and Innovative Technology Administration. Bureau of Transportation Statistics. Washington D.C. 